A REVIEW ON THERMODYNAMICS ANALYSIS AND WASTE ENERGY

\title{
UTILIZATION IN CEMENT INDUSTRY
}

\section{SACHIN VERMA ${ }^{1} \&$. SUDHIR Y KUMAR ${ }^{2}$}

${ }^{I}$ Research Scholar, College of Engineering and Technology Mody University Rajasthan, India

${ }^{2}$ Associate Professor College of Engineering and Technology Mody University Rajasthan, India

\begin{abstract}
In India, cement manufacturing process consumes about 15-20\% energy among all the energy consuming industries. Reduction in energy consumption in cement production process is the prime concern. Therefore, detailed review on the energy use and reserves is essential to find out energy wastage so that essential actions could be applied to decrease energy consumption. In this paper energy use at different sections of cement industries based on the thermodynamic analysis specially Exergy analysis, alternative fuel used for cement kilns, various energy savings measures were reviewed and presented.
\end{abstract}

KEY WORDS: Exergy Analysis, Cement Industries, Optimization Techniques For Energy Savings Etc

Received: Sep 08, 2017; Accepted: Sep 28, 2017; Published: Nov 08, 2017; Paper Id.: IJMPERDDEC201722

\section{INTRODUCTION}

India's cement industry accounted for over six percent of the world's annual cement production. Throughout the years innovation in the cement manufacturing technology, has created with a developing spotlight on manageable and furthermore cost and vitality effective generation. While huge strides may not appear to be noticeable on a year to year premise in Indian cement industry. Industrial sector energy consumption varies from $30 \%$ to $70 \%$ of total energy used in India. A generous amount of energy consumed in manufacturing of cement. [1]Thermal energy consider around $20-25 \%$ of the total cement production cost. The typical electrical energy consumption of a modern cement plant is about $110-120 \mathrm{kWh}$ per tonne of cement. Thus concentrate ought to be given on the diminishment of vitality and vitality related ecological discharges. It is important to discover the vitality misfortunes and limit it to bring down the vitality utilization. The Thermodynamic examination is the best instrument for streamlining. [3, 5, 6]

Thermodynamic Analysis and Optimization

Energy consumption represents the largest part of the production cost for cement factories and has a significant influence on product prices (Stanislav Boldyryev, 2016); the major part of the $\mathrm{CO}_{2}$ emissions from the production of cement is released from the calcinations of limestone (50\%) and from the combustion of fuels (40\%). [7]Waste heat recovery systems are already in operation in various industries with success. In Canada, the Gold Creek Power Plant [17] has a heat recovery system that produces 6.5MWpower using ORC technology. In India, the A. P. Cement Works with 4 MW and ORC technology is Heidelberger Zement AG Plant, in Lengfurt (Germany) [17] with 1.5 MW power and ORC technology. Another cement industry that uses waste heat recovery (S. Karellas, 
2013)

Keeping in mind the end goal to decrease energy utilization in concrete creation process, the cogeneration control plant can recuperate the waste warms to create electrical energy with no extra fuel utilization and along these lines diminish the high cost of electrical energy and $\mathrm{CO} 2$ emanations for bond generation. Since the waste heats in cement plant are classified as middle and low temperature waste heat, several power plants are particularly well suited for these waste heats available, [9] such as single flash steam cycle, dual-pressure steam cycle, ORC and the Kalina cycle. (Jiangfeng Wang, 2009)

To carry out a thermo economic analysis, the first step is to define the configuration of the system, which is also known as process flow diagram. The second step is the exergy analysis of the system, in order to calculate the exergy of each flow. The last step is the thermo economic analysis of the system, in which unit exergy costs of each process are calculated among other parameters. Processes which are characterised by having high unit exergy costs will be the less efficient $[11,12,13]$

Exergy examination is a present day investigation device, which is utilized for building forms. Exergy investigation is identified with both the primary law and second law of thermodynamics. [14] The primary reason for exergy investigation is, to distinguish the reasons for the defect of a vitality transformation process. Exergy investigation prompts a superior comprehension of the impact of thermodynamic procedures, on the procedure adequacy, correlation of the significance of various thermodynamic elements, and the assurance of the best methods for enhancing the procedure under thought [8]. A superior comprehension of locales of exergy decimations can help enhance the framework operation and help in better plan and advancement. A higher exergetic execution of a framework converts into vitality funds and ecological advantages. [15-20]

There have been many investigations about the cement part. Among them, there are vital and deductive papers, demonstrating both vitality way to deal with the cement industry and the possibilities and methods for development in vitality utilization of cement industry.

Table 1: Review Based on Thermal Analysis of Cement Manufacturing Process

\begin{tabular}{|l|l|l|l|}
\hline \multicolumn{1}{|c|}{ Author } & \multicolumn{1}{|c|}{ Objective } & \multicolumn{1}{|c|}{ Methodology } & \multicolumn{1}{c|}{ Conclusion } \\
\hline $\begin{array}{l}\text { Jiangfeng } \\
\text { Wang, } \\
2009\end{array}$ & $\begin{array}{l}\text { Exergy analyses and } \\
\text { parametric } \\
\text { optimizations for } \\
\text { different cogeneration } \\
\text { power plants in } \\
\text { cement industry }\end{array}$ & $\begin{array}{l}\text { Single flash steam cycle, dual- } \\
\text { pressure steam cycle, organic } \\
\text { Rankine cycle (ORC) and the } \\
\text { Kalina cycle are used for } \\
\text { cogeneration in cement plant. } \\
\text { The exergy investigation for } \\
\text { every cogeneration framework is } \\
\text { inspected, and a parameter } \\
\text { enhancement for every } \\
\text { cogeneration framework is } \\
\text { accomplished by methods for } \\
\text { hereditary calculation (GA) to } \\
\text { achieve the greatest exergy } \\
\text { productivity. }\end{array}$ & $\begin{array}{l}\text { The exergy losses in turbine, } \\
\text { condenser, and heat recovery vapor } \\
\text { generator are relatively large, and } \\
\text { reducing the exergy losses of these } \\
\text { components could improve the } \\
\text { performance of the cogeneration } \\
\text { system. }\end{array}$ \\
& & $\begin{array}{l}\text { Contrasted and different frameworks, } \\
\text { the Kalina cycle could accomplish the } \\
\text { best execution in bond plant. }\end{array}$ \\
& & \\
\hline
\end{tabular}




\begin{tabular}{|c|c|c|c|}
\hline $\begin{array}{l}\text { Stanislav } \\
\text { Boldyryev, } \\
2016\end{array}$ & $\begin{array}{l}\text { The improved heat } \\
\text { integration of cement } \\
\text { production under } \\
\text { limited process } \\
\text { conditions: A case } \\
\text { study for Croatia }\end{array}$ & $\begin{array}{l}\text { The authors analyzed the energy } \\
\text { consumption of a particular } \\
\text { cement factory accomplish the } \\
\text { best execution in bond plant. }\end{array}$ & $\begin{array}{l}\text { The energy consumption of the cement } \\
\text { factory can be reduced by } 30 \% \text {, with an } \\
\text { estimated recovery period of } 3.4 \\
\text { months. The execution of this retrofit } \\
\text { venture helps the plant's productivity } \\
\text { and enhances the natural effect of the } \\
\text { concrete assembling process. }\end{array}$ \\
\hline $\begin{array}{l}\text { S. Karellas, } \\
2013\end{array}$ & $\begin{array}{l}\text { Energetic and } \\
\text { exergetic analysis of } \\
\text { waste heat recovery } \\
\text { systems in the } \\
\text { cement industry }\end{array}$ & $\begin{array}{l}\text { Examine and compare } \\
\text { energetically and exergetically, } \\
\text { two different WHR (waste heat } \\
\text { recovery) techniques: a water- } \\
\text { steam Rankine cycle, and an } \\
\text { Organic Rankine Cycle (ORC). }\end{array}$ & $\begin{array}{l}\text { A parametric study proved that the } \\
\text { water steam technology is more } \\
\text { efficient than ORC in exhaust gases } \\
\text { temperature higher than } 310^{\circ} \mathrm{C} \text {. Finally } \\
\text { a brief economic assessment of the } \\
\text { most efficient solution was } \\
\text { implemented. WHR establishments in } \\
\text { concrete industry can contribute } \\
\text { fundamentally in the lessening of the } \\
\text { electrical utilizations working cost } \\
\text { along these lines being an extremely } \\
\text { alluring venture with a payback period } \\
\text { up to } 5 \text { years }\end{array}$ \\
\hline $\begin{array}{l}\text { Vedat Ari, } \\
2011\end{array}$ & $\begin{array}{l}\text { Energetic and } \\
\text { exergetic assessments } \\
\text { of a cement } \\
\text { rotary kiln system }\end{array}$ & $\begin{array}{l}\text { Energetic and exergetic analyses } \\
\text { of an existing rotary kiln system } \\
\text { are presented, and first and } \\
\text { second law efficiencies are } \\
\text { calculated. }\end{array}$ & $\begin{array}{l}\text { The energy and exergy efficiencies of } \\
\text { the existing system are } 54.9 \text { and } 28.1 \% \text {, } \\
\text { respectively. With the cogeneration, } \\
\text { these exergy efficiencies have been } \\
\text { obtained to be } 70.6 \% \text { for the use of } \\
\text { waste heat recovery steam generator } \\
\text { (WHRSG) and } 81.5 \% \text { for the use of } \\
\text { heat to pre-heat the raw material, } \\
\text { respectively, which dictates a } \\
\text { remarkable improvement over the } \\
\text { existing system }\end{array}$ \\
\hline $\begin{array}{l}\text { Ahmet } \\
\text { Kolip and } \\
\text { Ahmet } \\
\text { Fevzi } \\
\text { Savas, } \\
2010\end{array}$ & $\begin{array}{l}\text { Energy and exergy } \\
\text { analyses of a parallel } \\
\text { flow, four stage } \\
\text { cyclone precalciner } \\
\text { type cement plant }\end{array}$ & $\begin{array}{l}\text { A mathematical model related to } \\
\text { energy and exergy balance for } \\
\text { four-stage cyclone precalciner } \\
\text { type cement plant is developed. } \\
\text { The energy and exergy balances } \\
\text { for the whole system and each } \\
\text { unit are calculated and presented. }\end{array}$ & $\begin{array}{l}\text { The first and second law efficiencies } \\
\text { were } 51 \text { and } 28 \% \text {, respectively. Total } \\
\text { exergy loss of the system was found to } \\
\text { be about } 72 \% \text {. }\end{array}$ \\
\hline $\begin{array}{l}\text { Adem } \\
\text { Atmaca } \\
\text { Mehmet } \\
\text { Kanoglu, } \\
2012\end{array}$ & $\begin{array}{l}\text { Reducing energy } \\
\text { consumption of a raw } \\
\text { mill in cement } \\
\text { industry }\end{array}$ & $\begin{array}{l}\text { The first and second law analysis } \\
\text { of a raw mill is performed and } \\
\text { certain measures are actualized in } \\
\text { a current crude plant in a bond } \\
\text { production line keeping in mind } \\
\text { the end goal to decrease the } \\
\text { measure of vitality utilization in } \\
\text { crushing procedure. } \\
\text { The impacts of surrounding air } \\
\text { temperature and dampness } \\
\text { substance of crude materials on } \\
\text { the performance of the raw mill } \\
\text { are investigated }\end{array}$ & $\begin{array}{l}\text { The specific energy consumption for } \\
\text { farine production is determined to be } \\
24.75 \mathrm{kWh} / \text { ton farine. The use of an } \\
\text { external hot gas supply provides } 6.7 \% \\
\text { reduction in energy consumption } \\
\text { corresponding to a saving of } 1.66 \mathrm{kWh} \\
\text { per ton of farine production }\end{array}$ \\
\hline $\begin{array}{l}\text { DAN } \\
\text { SONG } \\
\text { BIN } \\
\text { CHENA } \\
2016\end{array}$ & $\begin{array}{l}\text { Extended Exergy } \\
\text { Accounting For } \\
\text { Energy Consumption } \\
\text { and } \mathrm{CO}_{2} \text { Emissions of } \\
\text { Cement Industry-A } \\
\text { Basic Framework }\end{array}$ & $\begin{array}{l}\text { Exergetic efficiency and } \mathrm{CO}_{2} \\
\text { emission targeted at a typical } \\
\text { cement production line are } \\
\text { examined in detail with key } \\
\text { factors of mitigation being } \\
\text { identified. }\end{array}$ & Some preliminary results are presented \\
\hline
\end{tabular}




\begin{tabular}{|c|c|c|c|}
\hline & & $\begin{array}{l}\text { the future emission trends are } \\
\text { simulated based on dynamic } \\
\text { prediction with different } \\
\text { optimization scenarios in view of } \\
\text { current mitigation targets }\end{array}$ & \\
\hline $\begin{array}{l}\text { Tahsin } \\
\text { Engin, } \\
\text { Vedat Ari, } \\
2005\end{array}$ & $\begin{array}{l}\text { Energy auditing and } \\
\text { recovery for dry type } \\
\text { cement rotary kiln } \\
\text { systems-A case } \\
\text { study }\end{array}$ & $\begin{array}{l}\text { The energy audit analysis of a dry } \\
\text { type rotary kiln system working } \\
\text { in a cement plant in Turkey. The } \\
\text { kiln has a capacity of } 600 \text { ton- } \\
\text { clinker per day }\end{array}$ & $\begin{array}{l}\text { About } 40 \% \text { of the total input energy } \\
\text { was being lost through hot flue gas } \\
(19.15 \%) \text {, cooler stack }(5.61 \%) \text { and } \\
\text { kiln shell ( } 15.11 \% \text { convection plus } \\
\text { radiation). Some possible ways to } \\
\text { recover the heat losses are also } \\
\text { introduced and discussed. Findings } \\
\text { showed that approximately } 15.6 \% \text { of } \\
\text { the total input energy ( } 4 \mathrm{MW}) \text { could be } \\
\text { recovered. }\end{array}$ \\
\hline $\begin{array}{l}\text { C. } \\
\text { Koroneos, } \\
2005\end{array}$ & $\begin{array}{l}\text { Exergy analysis of } \\
\text { cement production }\end{array}$ & $\begin{array}{l}\text { involves assessment of energy } \\
\text { and exergy input at each stage of } \\
\text { the cement production process }\end{array}$ & $\begin{array}{l}\text { It is found that } 50 \% \text { of the exergy is } \\
\text { being lost even though a big amount of } \\
\text { waste heat is being recovered. }\end{array}$ \\
\hline $\begin{array}{l}\text { Laila M. } \\
\text { sFarag, } \\
\text { Anter G. } \\
\text { Taghian, } \\
2015\end{array}$ & $\begin{array}{l}\text { Energy and exergy } \\
\text { analyses of Egyptian } \\
\text { cement kiln plants }\end{array}$ & Exergy Analysis & $\begin{array}{l}\text { Energetic efficiencies of the plants } \\
\text { were found to vary between } 41.6 \% \text { and } \\
55.5 \% \text { and their exergetic efficiencies } \\
\text { between } 26.8 \% \text { and } 35.6 \% \\
\text { respectively. Energy lost with bypass } \\
\text { gas and dust ranges from } 724.3 \mathrm{~kJ} / \mathrm{kg} \\
\text { clinker for the least efficient process to } \\
200.2 \mathrm{~kJ} / \mathrm{kg} \text { clinker for the highest } \\
\text { efficient one corresponding to } 16.6 \% \text { to } \\
6.1 \% \text { of the total heat input } \\
\text { respectively. }\end{array}$ \\
\hline $\begin{array}{l}\text { G. Kabir, } \\
\text { A. I. } \\
\text { Abubakar, } \\
\text { U. A. El- } \\
\text { Nafaty, } \\
2010\end{array}$ & $\begin{array}{l}\text { Energy audit and } \\
\text { conservation } \\
\text { opportunities, for pyro } \\
\text { processing unit of a } \\
\text { typical } \\
\text { dry process cement } \\
\text { plant }\end{array}$ & $\begin{array}{l}\text { Thermal energy audit analysis } \\
\text { was employed, on the pyro } \\
\text { processing unit of the cement } \\
\text { plant }\end{array}$ & $\begin{array}{l}\text { Thermal efficiency of the unit stands at } \\
41 \% \text {, below } 50-54 \% \text { achieved in } \\
\text { modern plants. The exhaust gases and } \\
\text { kiln shell heat energy losses are in } \\
\text { significant quantity, amounting to } \\
27.9 \% \text { and } 11.97 \% \text { of the total heat } \\
\text { input respectively. } \\
\text { Power and thermal energy savings of } \\
42.88 \mathrm{MWh} \text { /year and } 5.30 \mathrm{MW} \text { can be } \\
\text { achieved respectively. Financial } \\
\text { benefits for use of the conservation } \\
\text { methods are substantial. Environmental } \\
\text { benefit of } 14.10 \% \text { reduction in } \\
\text { Greenhouse gases (GHG) emissions } \\
\text { could be achieve }\end{array}$ \\
\hline $\begin{array}{l}\text { M. G. } \\
\text { Rasul, } \\
2005\end{array}$ & $\begin{array}{l}\text { Assessment of the } \\
\text { thermal performance } \\
\text { and energy } \\
\text { conservation } \\
\text { opportunities of a } \\
\text { cement industry in } \\
\text { Indonesia }\end{array}$ & $\begin{array}{l}\text { model is developed on the basis } \\
\text { of mass, energy and exergy } \\
\text { balance and is applied to an } \\
\text { existing Portland cement industry } \\
\text { in Indonesia }\end{array}$ & $\begin{array}{l}\text { The thermal energy conservation } \\
\text { opportunities are identifiedThis } \\
\text { investigation demonstrate that by } \\
\text { supplanting industrial diesel oil (IDO) } \\
\text { with squander warm recuperation from } \\
\text { oven and cooler fumes for drying of } \\
\text { crude feast and fuel, and preheating of } \\
\text { burning air, a security industry in } \\
\text { Indonesia can save around } 1.264 \times 105 \\
\text { US dollars for each year. }\end{array}$ \\
\hline
\end{tabular}




\begin{tabular}{|c|c|c|c|}
\hline $\begin{array}{l}\text { Ziya } \\
\text { Sogut, } \\
\text { Zuhal } \\
\text { Oktay, } \\
2008\end{array}$ & $\begin{array}{l}\text { Energy and exergy } \\
\text { investigations in a } \\
\text { warm procedure of a } \\
\text { creation line for a } \\
\text { concrete } \\
\text { manufacturing plant } \\
\text { and applications }\end{array}$ & $\begin{array}{l}\text { Determine the actual energy } \\
\text { losses by performing energy and } \\
\text { exergy analyses and to evaluate } \\
\text { energy and exergy efficiency in } \\
\text { each process for the cement } \\
\text { factory. In these examinations, } \\
\text { for each procedure energy and } \\
\text { exergy graphs have been } \\
\text { constituted on the creation line. }\end{array}$ & $\begin{array}{l}\text { Efficiencies (energy/exergetic) of the } \\
\text { processes for the raw mill, the rotary } \\
\text { kiln, the trass mill and the coal mill on } \\
\text { the production line have been found as } \\
84 \% / 25 \%, 61 \% / 49 \%, 74 \% / 13 \% \text {, } \\
74 \% / 18 \% \text {, respectively.. What's more, a } \\
\text { few proposals concerning the } \\
\text { diminishment of energy misfortunes } \\
\text { have been proposed. }\end{array}$ \\
\hline $\begin{array}{l}\text { M. Z } \\
\text { Sogut,Z } \\
\text { OKTEY,A } \\
\text { Hepbasli20 } \\
09\end{array}$ & $\begin{array}{l}\text { Energetic and } \\
\text { exergetic assessment } \\
\text { of a trass mill process } \\
\text { in a cement plant }\end{array}$ & $\begin{array}{l}\text { The main objective of this study } \\
\text { is to assess the performance of a } \\
\text { trass mill in a cement plant based } \\
\text { on the actual operational data } \\
\text { using energy and exergy analysis } \\
\text { method }\end{array}$ & $\begin{array}{l}\text { The overall exergy efficiencies are } \\
\text { found to be slightly less than the } \\
\text { corresponding energy efficiencies; e.g. } \\
74 \% \text { and } 10.68 \% \text { for energy and exergy } \\
\text { efficiency, respectively. } \\
\text { Using energy recovery systems, waste } \\
\text { heat energy may be captured, while } \\
\text { energy and exergy efficiency values } \\
\text { can be improved to } 84 \% \text { and } 48 \% \text {, } \\
\text { respectively. }\end{array}$ \\
\hline $\begin{array}{l}\text { Ziya } \\
\text { Sogut, } \\
\text { Zuhal } \\
\text { Oktay, } \\
2011\end{array}$ & $\begin{array}{l}\text { Impact assessment of } \\
\mathrm{CO}_{2} \text { emissions caused } \\
\text { by exergy losses in the } \\
\text { cement sector }\end{array}$ & $\begin{array}{l}\text { An exergy analysis is carried out } \\
\text { for all of the thermal processes of } \\
\text { the cement plant. Then exergy } \\
\text { losses and carbon dioxide (CO2) } \\
\text { emissions of the rotary kiln } \\
\text { process taken exemplary } \\
\text { according to annual dead state } \\
\text { temperature changes are } \\
\text { determined. }\end{array}$ & $\begin{array}{l}\text { Annual averages of the exergy } \\
\text { efficiency of the kiln and its exergetic } \\
\text { improvement potential are found as } \\
48.5 \% \text { and } 110.58 \mathrm{GJ} / \mathrm{h} \text {, respectively. } \\
\text { In this system, } \mathrm{CO} 2 \mathrm{emissions} \text { caused } \\
\text { by exergetic losses are calculated for } \\
\text { the coal mixture and the natural gas as } \\
\text { an average of } 38,004 \mathrm{~kg} / \mathrm{h} \text { and } 12,668 \\
\mathrm{~kg} / \mathrm{h} \text {, respectively. Toward the finish } \\
\text { of the examination, a few proposals } \\
\text { concerning lessening of the } \\
\text { worldwide impacts for these } \\
\text { frameworks are made.. }\end{array}$ \\
\hline $\begin{array}{l}\text { Ziya } \\
\text { Sogut, } \\
\text { Zuhal } \\
\text { Oktay, } \\
\text { Hikmet } \\
\text { Karakoç, } \\
2010\end{array}$ & $\begin{array}{l}\text { Mathematical } \\
\text { modeling of heat } \\
\text { recovery from a rotary } \\
\text { kiln }\end{array}$ & $\begin{array}{l}\text { In this study, heat recovery from } \\
\text { rotary kiln was examined for a } \\
\text { cement plant in Turkey. At initial, } \\
\text { an exergy investigation was } \\
\text { completed on the operational } \\
\text { information of the plant. A } \\
\text { mathematical model was } \\
\text { developed for a new heat } \\
\text { recovery exchanger for the plant }\end{array}$ & Ss \\
\hline $\begin{array}{l}\text { Zafer Utlu, } \\
\text { Ziya } \\
\text { Sogut, Arif } \\
\text { Hepbasli, } \\
\text { Zuhal } \\
\text { Oktay, } \\
\text { 2006 }\end{array}$ & $\begin{array}{l}\text { Energy and exergy } \\
\text { analyses of a raw mill } \\
\text { in a cement production }\end{array}$ & $\begin{array}{l}\text { Perform energy and exergy } \\
\text { analysis of a raw mill (RM) and } \\
\text { raw materials arrangement unit in } \\
\text { a bond plant in Turkey utilizing } \\
\text { the genuine operational } \\
\text { information. }\end{array}$ & $\begin{array}{l}\text { Proposed as a valuable instrument in } \\
\text { the examination of vitality and exergy } \\
\text { use, creating vitality strategies and } \\
\text { giving vitality preservation measures. }\end{array}$ \\
\hline $\begin{array}{l}\text { G. V. } \\
\text { Pradeep } \\
\text { Varma T. } \\
\text { Srinivas, } \\
2016\end{array}$ & $\begin{array}{l}\text { Parametric analysis of } \\
\text { steam flashing in a } \\
\text { power plant using } \\
\text { waste heat of cement } \\
\text { factory }\end{array}$ & $\begin{array}{l}\text { A case study has been conducted } \\
\text { at a cement factory, Telangana, } \\
\text { India with cogeneration plant } \\
\text { having flashing technology. }\end{array}$ & $\begin{array}{l}\text { The recognized key operational } \\
\text { parameters are steam producing weight, } \\
\text { point of confinement to high weight } \\
\text { blazing, breaking point to low weight } \\
\text { glimmering and blaze mass proportion }\end{array}$ \\
\hline
\end{tabular}

Energy Recovery from Waste to Utilize in Cement Plant

The cement manufacturing process is an energy exhaustive process. It yields weighty pollution and utilizes large amounts, on non-renewable resources. With increasing pressures to reduce greenhouse gas emissions, due to cement 
manufacture, research and development of fuel alternatives and their effect on the manufacturing process, has become an industry focus. The cement industry is a Resource Intensive Industry (RII), with use of large quantity of natural resources as Raw materials and Fuels. [21-22] The known fossil fuels and more importantly Coal, which is the primary fuel for Indian cement industry is fast depleting, it is imperative to look for alternatives. The cement industry is capable to co process wastes as alternate fuels and raw materials, to reinforce its competiveness and at the same time, contribute to solutions to some of society's waste problems in a way, which valorises the waste and is beneficial to the environment.[24]

The different studies done by different researchers are tabulated in Table 2 and 3, on the same era.

Table 2: Recent Studies Based on Energy Recovery from Waste to Utilize in Cement Plant

\begin{tabular}{|c|c|c|c|}
\hline Author & Objective & Methodology & Conclusion \\
\hline $\begin{array}{l}\text { K.T. } \\
\text { Kaddatz, } \\
\text { et al. } 2013\end{array}$ & $\begin{array}{l}\text { To meet the } \\
\text { requirements of } \\
\text { testing and } \\
\text { implementing } \\
\text { selected } \\
\text { alternative fuels. }\end{array}$ & $\begin{array}{l}\text { Simulation of three alternative } \\
\text { fuels, namely spent carbon lining, } \\
\text { used industrial lubricants and } \\
\text { used tires, for identifying the } \\
\text { most effective fuel source among } \\
\text { these three. } \\
\text { Aspen Plus software was initially } \\
\text { selected to model the cement } \\
\text { manufacturing process }\end{array}$ & $\begin{array}{l}\text { Among the selected fuels used, } \\
\text { industrial lubricant is found to be the } \\
\text { best option regarding the } \mathrm{CO} 2 \\
\text { emission, while the spent carbon lining } \\
\text { is the worst one. In contrast, feed } \\
\text { material requirements can be reduced } \\
\text { by up to approximately } 15 \% \text { by using } \\
\text { spent carbon lining }\end{array}$ \\
\hline $\begin{array}{l}\text { Emad } \\
\text { Benhelal, } \\
\text { Alireza } \\
\text { Rafiei } \\
2012\end{array}$ & $\begin{array}{l}\text { Evaluate the air } \\
\text { pollution } \\
\text { reduction through } \\
\text { fuel substitution } \\
\text { of coal with fuel } \\
\text { oil, natural gas } \\
\text { and palm kernel } \\
\text { shell. }\end{array}$ & $\begin{array}{l}\text { This paper introduces the re- } \\
\text { enactment of concrete process } \\
\text { utilizing elective energizes to } \\
\text { supplant coalPyro-processing } \\
\text { stage of the conventional cement } \\
\text { manufacturing process was } \\
\text { simulated by Aspen HYSYS }\end{array}$ & $\begin{array}{l}\text { Simulation results revealed that the } \\
\text { substitution of fuel oil, natural gas and } \\
\text { palm kernel shell for coal had a critical } \\
\text { commitment for emanation decrease in } \\
\text { concrete industry. }\end{array}$ \\
\hline $\begin{array}{l}\text { U. } \\
\text { Kaantee } \\
\text { et al } 2004\end{array}$ & $\begin{array}{l}\text { The goal is to } \\
\text { optimise process } \\
\text { control and } \\
\text { alternative fuel } \\
\text { consumption, } \\
\text { while maintaining } \\
\text { clinker product } \\
\text { quality }\end{array}$ & $\begin{array}{l}\text { In order select a suitable } \\
\text { alternative fuel, a commercial } \\
\text { modelling tool (ASPEN PLUS) is } \\
\text { used to model the four-stage } \\
\text { preheater kiln system of a full- } \\
\text { scale cement plant using petcoke } \\
\text { as fuel. } \\
\text { Counts with elective fills are } \\
\text { finished by incompletely } \\
\text { supplanting the essential or } \\
\text { auxiliary fuel. Meat and bone } \\
\text { meal (MBM) and sewage slime } \\
\text { are considered }\end{array}$ & $\begin{array}{l}\text { Dependence of process performance } \\
\text { on the amount of combustion air is } \\
\text { clearly demonstrated } \\
\text { The vitality demand of the procedure } \\
\text { could be anticipated for differing fuel } \\
\text { blends }\end{array}$ \\
\hline $\begin{array}{l}\text { Azad } \\
\text { Rahman } \\
\text { et al } 2014\end{array}$ & $\begin{array}{l}\text { Aspen Plus based } \\
\text { simulation for } \\
\text { energy recovery } \\
\text { from waste to } \\
\text { utilize in cement } \\
\text { plant pre heater } \\
\text { tower }\end{array}$ & $\begin{array}{l}\text { A process model of the pre heater } \\
\text { tower is developed using Aspen } \\
\text { Plus simulation software based on } \\
\text { the combustion mechanism. } \\
\text { The model is verified against } \\
\text { measured data from industry and } \\
\text { data available in the literature. }\end{array}$ & $\begin{array}{l}\text { That maximum } 3 \% \text { increase of energy } \\
\text { efficiency and } 2.5 \% \text { reduction of } \mathrm{CO} 2 \\
\text { can be achieved by using tyre for } \\
\text { about } 25 \% \text { of thermal energy } \\
\text { requirement. Recreation comes about } \\
\text { displayed in this paper offer a rule for } \\
\text { actualizing chose squander inferred } \\
\text { powers in bond industry. }\end{array}$ \\
\hline $\begin{array}{l}\text { Seyed Ali } \\
\text { Ashrafiza } \\
\text { deh et al, } \\
2012\end{array}$ & $\begin{array}{l}\text { Exergetic and } \\
\text { environmental } \\
\text { performance } \\
\text { improvement in } \\
\text { cement production }\end{array}$ & $\begin{array}{l}\text { The burning system of the cement } \\
\text { production (kiln \& pre heater) } \\
\text { process was simulated in four } \\
\text { thermal areas. }\end{array}$ & $\begin{array}{l}\text { it was shown that the secondary burner } \\
\text { application can reduce the exergy } \\
\text { losses about } 25 \text { percent, which leads to } \\
\text { a reduction of the greenhouse gases of } \\
\text { about } 35000 \text { cubic meters per year for }\end{array}$ \\
\hline
\end{tabular}




\begin{tabular}{|l|l|l|l|}
\hline & $\begin{array}{l}\text { process by driving } \\
\text { force distribution }\end{array}$ & each ton per day of clinker production \\
\hline
\end{tabular}

Table 3: Different Industrial Waste used as Alternative Fuel in Cement Production

\begin{tabular}{|c|c|c|}
\hline Fuel & Suitability & Reference \\
\hline $\begin{array}{l}\text { Spent carbon } \\
\text { lining }\end{array}$ & $\begin{array}{l}\text { - Its ability of offset a portion of the feed material } \\
\text { required } \\
\text { - } \quad \text { Limited though by its sodium content } \\
\text { nourish necessities are fundamentally the same as that for coal } \\
\text { and would require negligible changes. }\end{array}$ & \multirow{3}{*}{$\begin{array}{l}\text { K. T. Kaddatz, } \\
\text { et al. } 2013\end{array}$} \\
\hline $\begin{array}{l}\text { Used industrial } \\
\text { lubricants }\end{array}$ & $\begin{array}{l}\text { - } \\
\text { high } \\
\text { - } \\
\text { Produced the low overall carbon dioxide emissions } \\
\text { genuinely straightforward and would require insignificant } \\
\text { changes to the present plant Largest adjustment would be the } \\
\text { range required for the capacity, pumping and mixing }\end{array}$ & \\
\hline Used tires & $\begin{array}{l}\text { - The tires had a high energy content allowing them to } \\
\text { provide a better emissions profile than coal. } \\
\text { the biggest shortcoming with utilizing this alternative is } \\
\text { that tires requires a convoluted taking care of setup which } \\
\text { regularly incorporates a lot of manual taking care of. }\end{array}$ & \\
\hline Fuel oil & $\begin{array}{l}\text { - Second largest pollution emitter after coal since } \\
\text { produces } 31,400 \mathrm{~kg} / \mathrm{h} \mathrm{CO}_{2} \text { and was the first } \mathrm{SO}_{2} \\
\text { producer. }\end{array}$ & \multirow{3}{*}{$\begin{array}{l}\text { Emad } \\
\text { Benhelal, } \\
\text { Alireza Rafiei } \\
2012\end{array}$} \\
\hline $\begin{array}{l}\text { Palm kernel } \\
\text { shell }\end{array}$ & $\begin{array}{l}\text { - Reduced } 46.16 \% \text { of } \mathrm{CO}_{2}, 73 \% \text { of } \mathrm{NO}_{2} \text { and } 68 \% \text { of } \mathrm{SO}_{2} \\
\text { emissions as compare to burning coal. }\end{array}$ & \\
\hline Natural gas & $\begin{array}{l}\text { - Mitigated } 45.64 \% \text { of carbon emissions and produced } \\
\text { neither } \mathrm{NO}_{2} \text { nor } \mathrm{SO}_{2} \text {. }\end{array}$ & \\
\hline $\begin{array}{l}\text { Meat and bone } \\
\text { meal (MBM) } \\
\text { and Sewage } \\
\text { sludge }\end{array}$ & $\begin{array}{l}\text { - The air demand is higher with the new fuel than for the } \\
\text { coal, it means that the kiln fans must run at higher speed } \\
\text { to supply the bigger air sums. Then also the exhaust gas } \\
\text { amounts are larger, which will affect the whole function } \\
\text { of the pre-heating system as a whole. }\end{array}$ & $\begin{array}{l}\text { U. Kaantee et } \\
\text { al 2004, Azad } \\
\text { Rahman } 2014\end{array}$ \\
\hline
\end{tabular}

\section{CONCLUSIONS}

Cement manufacturing is an energy intensive process. This review paper explains Thermodynamic analysis of cement manufacturing plants along with use of alternative fuels or waste heat recovery was analyzed by various researchers. Amongst the different segments, grinding consumes about $60 \%$ of total energy consumption in a cement plant. Energy loss is maximum in grinding process. Therefore, enhancements can be made in this section to decrease heat loss or recycle heat. Use of alternative fuels or waste heat recovery could be a good solution. However, challenges associated with the use of alternative fuels must be overcome. This could be a potential area for future research and development. 


\section{REFERENCES}

1. K.T. Kaddatz, M.G. Rasul, Azad Rahman. 2013, "Alternative fuels for use in cement kilns: process impact modelling”, $5^{\text {th }}$ BSME International Conference on Thermal Engineering, Procedia Engineering 56 (2013) 413 - 420

2. Azad Rahman, M.G. Rasul, M.M.K. Khan, S. Sharma, 2013, "Impact of alternative fuels on the cement manufacturing plant performance: an overview”, $5^{\text {th }}$ BSME International Conference on Thermal Engineering, Procedia Engineering 56 (2013) $393-400$

3. Constantinos S. Psomopoulos, Nickolaos Chatziaras and Nickolas J. Themelis, 2016, "Use of waste derived fuels in cement industry: a review”, Management of Environmental Quality: An International Journal

4. Emad Benhelal, Alireza Rafiei 2012, "Overview of Process Modeling Software: Utilizing Alternative Fuels in Cement Plant for Air Pollution Reduction", Energy Science and Technology Vol. 4, No. 1, 2012, pp. 10-18 DOI:10.3968/j.est.1923847920120401.356

5. U. Kaantee, R. Zevenhoven, R. Backman, M. Hupa, 2004, "Cement manufacturing using alternative fuels and the advantages of process modelling”, Fuel Processing Technology 85 (2004) 293-301, doi:10.1016/S0378-3820(03)00203-0

6. Jiangfeng Wang, Yiping Dai, Lin Gao, 2009, "Exergy analyses and parametric optimizations for different cogeneration power plants in cement industry”, Applied Energy 86 (2009) 941-948, doi:10.1016/j.apenergy.2008.09.001

7. Stanislav Boldyryev, Hrvoje Mikulcic, Zoran Mohorovic, Milan Vujanovic, Goran Krajacic, Neven Duic, 2016, "The improved heat integration of cement production under limited process conditions: A case study for Croatia”, Applied Thermal Engineering 105 (2016) 839-848, http://dx.doi.org/10.1016/j.applthermaleng.2016.05.139

8. Azad Rahman, M.G. Rasul, M.M.K. Khan, S. Sharma, 2014, "Aspen Plus based simulation for energy recovery from waste to utilize in cement plant preheater tower", The $6^{\text {th }}$ International Conference on Applied Energy - ICAE2014, Energy Procedia $61(2014) 922-927$

9. S. Karellas, A.-D. Leontaritis, G. Panousis, E. Bellos, E. Kakaras 2013, "Energetic and exergetic analysis of waste heat recovery systems in the cement industry”, Energy 58 (2013) 147-156, http://dx.doi.org/10.1016/j.energy.2013.03.097

10. Vedat Ari, 2011, "Energetic and exergetic assessments of a cement rotary kiln system", Scientific Research and Essays Vol. 6(6), pp. 1428-1438, 18 March, 2011, DOI: 10.5897/SRE11.030

11. Jagmeet Sing \& Jaspal Singh, Sustainable Use of Industrial Waste in Cement Industry, International Journal of Environment, Ecology, Family and Urban Studies (IJEEFUS), Volume 6, Issue 3, May - June 2016, pp. 45-54

12. Ahmet Kolip and Ahmet Fevzi Savas, 2010, "Energy and exergy analyses of a parallel flow, fourstage cyclone precalciner type cement plant", International Journal of the Physical Sciences Vol. 5(7), pp. 1147-1163, July 2010

13. Seyed Ali Ashrafizadeh, Majid Amidpour, and Ali Allahverdi, 2012, "Exergetic and environmental performance improvement in cement production process by driving force distribution”, Korean J. Chem. Eng., 29(5), 606-613 (2012) DOI: 10.1007/s11814-011-0226-y

14. Adem Atmaca Mehmet Kanoglu, 2012, “Reducing energy consumption of a raw mill in cement industry”, Energy 42 (2012) 261-269, doi:10.1016/j.energy.2012.03.060

15. Dan Song, Bin Chena, 2016, "Extended Exergy Accounting for Energy Consumption and $\mathrm{CO}_{2}$ Emissions of Cement IndustryA Basic Framework", CUE2015-Applied Energy Symposium and Summit 2015: Low carbon cities and urban energy systems, Energy Procedia 88 (2016) 305 - 308, doi: 10.1016/j.egypro.2016.06.145

16. Tahsin Engin, Vedat Ari, 2005, "Energy auditing and recovery for dry type cement rotary kiln systems-A case study”, Energy 
Conversion and Management 46 (2005) 551-562, doi:10.1016/j.enconman.2004.04.007

17. C. Koroneos, G. Roumbas and N. Moussiopoulos, 2005, "Exergy analysis of cement production”, Int. J. Exergy, Vol. 2, No. 1, 2005.

18. Laila M. Farag, Anter G. Taghian, 2015, "Energy and exergy analyses of Egyptian cement kiln plants”, IJISET - International Journal of Innovative Science, Engineering \& Technology, Vol. 2 Issue 9, September 2015.

19. G. Kabir, A.I. Abubakar, U.A. El-Nafaty, 2010, "Energy audit and conservation opportunities for pyro processing unit of a typical dry process cement plant”, Energy 35 (2010) 1237-1243, doi:10.1016/j.energy.2009.11.003

20. M.G. Rasul, W. Widianto, B. Mohanty, 2005, "Assessment of the thermal performance and energy conservation opportunities of a cement industry in Indonesia", Applied Thermal Engineering 25 (2005) 2950-2965, doi:10.1016/j.applthermaleng.2005.03.003

21. Ziya Sogut, Zuhal Oktay, 2008, "Energy and exergy analyses in a thermal process of a production line for a cement factory and applications", Int. J. Exergy, Vol. 5, No. 2, 2008

22. M.Z. Sogut, Z. Oktay, A. Hepbasli, 2009, "Energetic and exergetic assessment of a trass mill process in a cement plant", Energy Conversion and Management 50 (2009) 2316-2323, doi:10.1016/j.enconman.2009.05.013

23. Ziya Sogut, Zuhal Oktay, 2011, "Impact assessment of CO2 emissions caused by exergy losses in the cement sector", Int. J. Exergy, Vol. 9, No. 3, pp.280-296

24. Ziya Sogut, Zuhal Oktay, Hikmet Karakoç, 2010, "Mathematical modeling of heat recovery from a rotary kiln”, Applied Thermal Engineering 30 (2010) 817-825, doi:10.1016/j.applthermaleng.2009.12.009

25. Camdali U, Erisen A, Celen F (2004). Energy and Exergy Analyses in a Rotary Burner with Pre-calcinations in Cement Production. Energy Conv. Manage., 44(18-19): 3017-3031.

26. Çengel Y, Boles M (2008). Thermodynamics an Engineering Approach 6th Edition, Dept. of Mechanical Engineering, University of Nevada: Reno, USA.

27. Zafer Utlu, Ziya Sogut, Arif Hepbasli, Zuhal Oktay, 2006, "Energy and exergy analyses of a raw mill in a cement production", Applied Thermal Engineering 26 (2006) 2479-2489, doi:10.1016/j.applthermaleng.2005.11.016

28. G. V. Pradeep Varma T. Srinivas, 2016, "Parametric analysis of steam flashing in a power plant using waste heat of cement factory", $5^{\text {th }}$ International Conference on Advances in Energy Research, ICAER 2015, 15-17 December 2015, Mumbai, India.doi: 10.1016/j.egypro.2016.11.174

29. Dogan S (2007). Cement Industry in Cukurova. I. Industrization and Environment Symposium Cukurova, Turkey; 13-14.

30. Engin T, Ari V (2005). Energy Auditing and Recovery for Dry Type Cement Rotary Kiln Systems - A Case Study, Energy Conv. Manage., 46(4): 551-562.

31. Kabir G, Abubakar AI, El-Nafaty UA (2010). Energy Audit and Conservation Opportunities for Pyroprocessing Unit of a Typical Dry Process Cement Plant. Energy, 35(3): 1237-1243.

32. Karbassi AR, Jafari HR, Yavari AR, Kalal H, Sid H (2010). Reduction of Environmental Pollution through Optimization of Energy Use In Cement Industries, Int. J. Environ. Sci., 7(1):127-134.

33. UTCP (Union of Turkish Cement Productions) Report (2008). Energy Management and Saving Opportunity in the Cement Productions: The Congress of the Energy Productivity, 11-12 January. 
34. Utlu Z, Hepbasli A (2007). A Review and Assessment of the Energy Utilization Efficiency in TheTurkish Industrial Sector Using Energy And Exergy Analysis Method", Renewable Sustainable Energy Rev., 11: 1438-1459.

35. Wang J, Yiping D, Lin G (2009). Exergy Analyses and Parametric Optimizations for Different Cogeneration Power Plants in Cement Industry. Applied Energy, 86: 941-948.

36. Worrell E, Martin N, Price L (2000). Potentials for Energy Efficiency Improvement in the US Cement Industry Energy, 25(12): 1189-1214.

37. Locher G (2002b). Mathematical Models for the Cement Clinker Burning Process Part.3. ZKG, 3: 69-80.

38. Moran MJ (1982). Availability Analysis: A Guideto Efficient Energy Use. New Jersey: Prentice Hall.

39. Morris DR Szargut J (1986). Standard Chemical Exergy of some Elements and Compound on the Planet Earth", Energy, V2 (8).

40. Peray EK (1979). Cement Manufacturers Handbook. USA: ChemicalPublishing Co.Report TUBITAK TTGV Science Technology Discussion (1997). ThePolicity of Energy Technologies, 1. Subgroups, Nowember.

41. M, Hammache A (2002). Introduction to the concept of exergy-for abetter understanding of low-temperature-heating and high-temperature cooling systems. IEA ANNEX37 